\title{
Life history and systematics of Albusambia elaphoglossumae (Lepidoptera: Crambidae): A new genus and species of musotimine with leaf-mining biology from Costa Rica
}

\author{
M. Alma Solis ${ }^{1}$, Donald R. Davis ${ }^{2} \&$ Kenji Nishida ${ }^{3}$ \\ 1 Systematic Entomology Laboratory, PSI, Agricultural Research Service, U. S. Department of Agriculture, c/o National \\ Museum of Natural History, Washington, D.C., 20560-0168, U.S.A., asolis@sel.barc.usda.gov \\ 2 Department of Entomology, Smithsonian Institution, Washington, D.C., 20560-0127, U.S.A., \\ davis.don@nmnh.si.edu \\ 3 Sistema de Estudios de Posgrado en Biología, Escuela de Biología, Universidad de Costa Rica, 2060 San José, Costa \\ Rica.knishida@cariari.ucr.ac.cr
}

Received 15-V-2004. Corrected 09-II-2005. Accepted 10-II-2005.

\begin{abstract}
Albusambia elaphoglossumae Solis \& Davis, a new genus and species, is described. It was discovered mining the fronds of the fern Elaphoglossum conspersum in Costa Rica (San José and Cartago Provinces, at elevations of 2300-3100 m). The type series was obtained by rearing of the immature stages in laboratory. The adult is defined by unique genital characters, and the pupa with a medial depression on the vertex and with two anterolateral horn-like structures on the prothorax. The larva is a gregarious leaf miner with its body flattened dorsoventrally and head prognathous; morphological adaptations to its leaf-mining habit are new to the Musotiminae. Fern-feeding musotimines are important to the discovery of new biological control agents for invasive ferns. Rev. Biol. Trop. 53(3-4): 487-501. Epub 2005 Oct 3.
\end{abstract}

Key words: Elaphoglossum conspersum, E. biolleyi, gregarious larvae, fern, leaf miner, Neotropical, Neurophyseta, Proacrias, Undulambia.

Recent collecting in the Cordillera de Talamanca of Costa Rica resulted in the discovery of a new genus and species of a musotimine crambid mining fronds of the fern, Elaphoglossum conspersum H. Christ (Pteridophyta: Lomariopsidaceae) (Figs. 1-3). The mining habit in the Pyraloidea is not common. Other New World musotimines have been reared feeding on ferns. These are Undulambia polystichalis (Capps), reared from leather leaf fern, Rumohra adiantiformis [=Polystichum adiantiforme (G. Forst) Small] Ching (Dryopteridaceae) (Kuitert and Dekle 1962). In 2002, Neurophyseta camptogrammalis (Hampson) was reared from Alsophila firma (Baker) D.S. Conant (Cyatheaceae) (Janzen and Hallwachs database homepage). Musotiminae is comprised of 18 genera and about 200 species worldwide; 50 or more species and five to seven genera from Asia and the South Pacific are still undescribed (S.-H. Yen, pers. comm.). There are nine genera and 82 species of Musotiminae in the Western Hemisphere, including Albusambia. Musotimines are defined by their laterally compressed antennae with flattened segments, $\mathrm{R}_{2}$ stalked with $\mathrm{R}_{3}+\mathrm{R}_{4}$ (but not in Albusambia), a reduced coecum in the aedeagus of the male genitalia, and enlarged tympanal cases (Minet 1985, Yoshiyasu 1985, Yen 1996). The relationship of Albusambia to other genera is unknown, although it is externally most similar to Neurophyseta Hampson. The genus Undulambia Lange contains three species from Florida and is the only genus of Musotiminae found in the U.S. Lange (1956) placed it in 
Nymphulinae, a subfamily known for its true aquatic caterpillars. Munroe (1972) later placed Undulambia in a new, separate tribe, Ambiini, within Nymphulinae, because $U$. polystichalis was terrestrial and fed on ferns. Munroe (1972) also noted that Musotima Meyrick (in Musotimini) larvae were terrestrial and fed on ferns. Speidel (1984) separated and raised to subfamily rank the Musotiminae, including Ambiini from Nymphulinae, based on characters of the genitalia and immatures.

In this paper, we describe the life history of Albusambia elaphoglossumae as well as all life-stages in detail. The species is compared to U. polystichalis and species of Neurophyseta.

\section{MATERIALS AND METHODS}

The eggs, larvae, and pupae were collected in Costa Rica in an oak forest near the Pan American Highway at Villa Mills, Cerro de la Muerte (San José province) (Fig. 1), and CATIE (Centro Agronómico Tropical de Investigación y Enseñanza) Biological Station in Cuericí (Cartago province), at elevations between 2800 and $3100 \mathrm{~m}$. Larvae from E. conspersum were first collected in January 1998 at the end of the wet season and reared by Donald R. Davis (DRD). The wet season in this area extends from April through December or January. Heavy rains are common during these months, with a yearly annual rainfall of $2812 \mathrm{~mm}$ (Kappelle 1996). During the dry season in the year 2000, Kenji Nishida (KN) visited the same area and began collecting additional material, by inspecting fronds and conducting extensive observations in the field. In this region, the dry season starts in December or January and ends in mid- to late April. Although the rain is infrequent, the humidity remains high and dense fog is common in the afternoons. The annual average temperature is $10.9^{\circ} \mathrm{C}$, and the temperature sometimes decreases to $-3^{\circ} \mathrm{C}$ during the dry season (Kappelle 1996).

Immature stages with the fronds collected by $\mathrm{KN}$ were placed in transparent plastic bags and taken into an air-conditioned room $\left(16-18^{\circ} \mathrm{C}\right)$ in the Museo de Insectos, Universidad de Costa Rica, UCR (San Pedro de Montes de Oca, $1150 \mathrm{~m}$ ), or were placed in a refrigerator $\left(7.0-8.0^{\circ} \mathrm{C}\right)$ for approximately 16 hours and then at room temperature $\left(20^{\circ} \mathrm{C}\right)$ for eight hours daily. A subset of specimens of immature stages were preserved in alcohol and deposited in the USNM.

The host plant, E. conspersum, is common in dense understory growth at several moist, well-shaded sites along roads (Fig. 2). Vegetation associated with $E$. conspersum consists of a tropical montane rain forest densely populated by temperate elements such as black oaks (Quercus costaricensis Liebm.) (Fagaceae), with more scattered white oak ( $Q$. copeyensis C. H. Muller) (Hartshorn 1983). Other abundant, principally understory species in this association include Schefflera rodriguesiana Frodin ex M. Cannon and Cannon (Araliaceae), Weinmannia pinnata L. (Cunoniaceae), Cavendishia bracteata (Ruiz and Pav. ex J. St.-Hil.) Hoerold, Vaccinium consanguineum Klotzsch (Ericaceae); Miconia biperulifera Cogn., M. schnellii Wurdack (Melastomataceae); and several species of Chusquea (Poaceae) (KN, pers. observ.).

\section{RESULTS}

\section{Albusambia Solis and Davis, n. gen.}

Diagnosis: Base color of body shiny white; wing margins not incised; forewing costal swelling absent; male genitalia with valva curved in above junction of tegumen and vinculum and continuing less broadly to anterior end. Larva dorsoventrally flattened; head prognathous, mandibles with two rows of serrations. Pupa with vertex of head round and with prominent medial dorsoventral depression; prothorax smooth dorsally, not square, with two anterolateral horn-like structures that protrude only slightly; anus posteriorly with lateral conical depressions.

Comparison to other taxa: Albusambia is compared to Undulambia in Capps (1965) and Neurophyseta in Phillips and Solis (1996). 
The basal color of Undulambia adults is brown, not white, as in Albusambia and Neurophyseta. Wings of Undulambia are incised, and those of Albusambia and Neurophyseta are entire. Forewing costal swelling is absent in Albusambia and Neurophyseta, but present in Undulambia. In the male genitalia of Undulambia the valva is long and equal in width throughout, not widened posteriorly as in Albusambia and some Neurophyseta species. The body of Undulambia larva is round, not dorsoventrally flattened, and not intersegmentally constricted as in Albusambia. In Undulambia the mandible consists of one line of teeth, not two as in that of Albusambia. Other than the host plant record, the biological and morphological data of the larvae of Neurophyseta are not available. Unlike the vertex of the pupal head of Albusambia, Undulambia does not have a prominent medial dorsoventral depression. Undulambia has a somewhat rugose, broadly flattened prothorax with two anterolateral horn-like structures that protrude twice as much as in the smooth prothorax of Albusambia. Albusambia has lateral conical depressions posterior to the anus, but Undulambia lacks these depressions. Pupal data on Neurophyseta is incomplete.

Etymology: The prefix of the generic epithet is derived from the Latin "albus" referring to the white base color of the adult moths, and "ambia" meaning "around" in Latin and referring to its relatedness to other genera in the subfamily. The gender of the genus is feminine.

Type species: Albusambia elaphoglossumae Solis and Davis.

\section{Albusambia elaphoglossumae \\ Solis and Davis, n. sp.}

Adult (Figs. 4-6): Head (Figs. 19-20): Frons and vertex white, vertex protruding from head higher than eye; labial and maxillary palpi three-segmented, white, black laterally; third labial palpus acute, third maxillary palpus round. Proboscis short, only slightly longer than labial palpi. Antennae prismatic, laterally compressed. Chaetosemata and ocelli absent.
Thorax: Dorsally white; patagium and tegula white, a few specimens with tegula grey and metathorax dorsally grey. Forelegs white, mediolaterally black; midleg and hindleg white, midleg with one pair of tibial spurs, hindleg with two pairs of tibial spurs.

Forewing (Fig. 21) [Refer to Phillips and Solis, 1996, Fig. 7 for venation terminology]: length $=6.91 \mathrm{~mm}$ (range: $6.0-8.1 \mathrm{~mm})(\mathrm{n}=36)$; margins not incised. Costal swelling absent. $\mathrm{R}_{1}$ and $\mathrm{R}_{2}$ from discal cell; $\mathrm{R}_{5}$ short stalked with $\mathrm{R}_{3+4}$, stalked about two-thirds its length. Basal band black, basal area white with scattered black scale, antemedial band black, antemedial area white, reniform spot black, postmedial line black, black spots between $R_{4}$ and $R_{5}$ and on $M_{3}$, fringe white with black patches on $M_{3}$ and $\mathrm{CuA}_{2}$; a few specimens mostly black posterior to and slightly above M-CuA line to posterior margin, antemedial and postmedial lines broader, black lines to outer margin from postmedial line on $\mathrm{M}_{3}$ and $\mathrm{CuA}_{2}$, a black line parallel to postmedial line from $\mathrm{M}_{3}$ to posterior margin. Underside white with postmedial line slightly visible with black scales, some black at basal area near costa; slightly darker specimens with similar color and pattern on underside as on upperside.

Hindwing (Fig. 21): Antemedial and postmedial line black, black discal spot, c-shaped mark from Rs to costal margin at intersection of $\mathrm{Sc}+\mathrm{R}_{1}$ and Rs, fringe white with black patches on $\mathrm{R}_{5}, \mathrm{M}_{3}$, and $\mathrm{CuA}_{2}$; a few specimens black basally to postmedial line, with broad black lines to outer margin including fringe at Rs, $\mathrm{M}_{3}$, and $\mathrm{CuA}_{2}$, less broad black lines at $\mathrm{M}_{1}$ and $\mathrm{CuA}_{1}$, and fringe from base to postmedial line. Underside white with antemedial and postmedial line slightly visible with black scales; slightly darker specimens with similar color and pattern on underside as on upperside. Female frenulum with three setae, male with one seta.

Abdomen: White. Tympanal organs (Fig. 22): Tympanal cases (=bulla tympani, caisses tympaniques) enlarged, processes tympani (=sailles tympaniques) absent, ramus tympani short, highly sclerotized.

Male genitalia (Figs. 25-28): Uncus long and finger-like; gnathos broadened posteriorly 
with sclerotized teeth dorsally; juxta simple, oblong; transtilla membranous medially; valva simple, broad posteriorly, curved in above junction of tegumen and vinculum and continuing less broadly to anterior end. Aedeagus simple without cornuti, almost as long as genital capsule; coecum extremely short, almost absent.

Female genitalia (Figs. 29-30): Corpus bursae only slightly longer than seventh segment, without signum, no clear distinction between ductus bursae and corpus bursae, ductus seminalis at about halfway between ostium bursae and corpus bursae, ostium bursae membranous, anterior apophyses four times as long as posterior apophyses, papillae analis dorsoventrally flattened.

Egg (Figs. 7-10): Flat, oval shape, size ca. $1.0 \mathrm{~mm} \times 0.5 \mathrm{~mm}$, pale creamy-yellow in clusters; empty egg shells grayish-brown.

Larva (Figs.11-15, 31-38): Five larval instars present. Last instar length $11.6 \mathrm{~mm}$ $12.0 \mathrm{~mm}(\mathrm{n}=4)$ (penultimate instar: $6.38 \mathrm{~mm}$; range: $6.1-6.5 \mathrm{~mm} ; \mathrm{n}=5$ ), dorsoventrally flattened. Head prognathous, yellowish with dark brown sutures; epicranial suture not present; frontoclypeus and labrum brown, more than twice as long as wide; two stemmata; $\mathrm{C} 1$ and $\mathrm{C} 2$ approximate, $\mathrm{F} 1$ at middle of frons, $\mathrm{AF} 1$ and AF2 located dorsally on adfrontal area; labrum with six setae on each side externally and three setae on each side internally, medially setose; mandible with two rows of serrations. T1-3 and A1-10 integument smooth, all segments with medially located dorsal and ventral sclerotized plates, prothoracic shield twice as wide as other dorsally sclerotized plates, setae with concolorous pinacula, intersegmentally constricted. Prothoracic shield yellow with clear platelets; $\mathrm{T} 1$ with two L setae anterior to spiracle. A1 and A7 with D1 on membrane or on margin of pinaculum, L1 and L2 on same pinaculum, L1 more than seven times as long as L2 on all segments. A8 D1 and D2 approximate on pinaculum, SD1 approximate to spiracle, spiracle six times larger than other abdominal spiracles, dorsally located, two L setae on same pinaculum. A9 with D1 just anterior to SD1 sometimes located on membrane and not on pinaculum, $1 \mathrm{~L}$ setae.
A10 with D2, SD1, and SD2 at outer margin of anal shield. Prolegs with crochets uniordinal in an incomplete circle (in a few specimens circle appears complete or in transverse bands); A1, A2, and A7 segments with ventral proleg-like protuberances without crochets.

Pupa (Figs.17-18, 23-24): Length: 6.83 $\mathrm{mm}$ (range: $6.0-7.7 \mathrm{~mm}$; $\mathrm{n}=10$ ). Ventral view: Round top of head with a prominent medial dorsoventral depression; labial palpus a small triangle posterior to labrum; labrum bilobed; pilifers not prominent; maxillary palpus absent; forefemur visible, prothoracic legs (foreleg) three-quarters length of forewing, mesothoracic leg (midleg) extends entire length of forewing and antenna extending about seveneighths length of forewing; hind tarsus extends just beyond length of forewing; abdominal segments 5 and 6 with vestigial prolegs; abdominal segment 8-10 with genital orifice anteriorly, anus posteriorly with lateral conical depressions. Dorsal view: prothorax smooth, not square-shaped with two dorsolateral horn-like structures that protrude only slightly; mesothorax with four and metathorax with two tiny setae; abdominal segments with spiracles extruded slightly, abdominal segments three to seven dorsally with short medially located setae; cremaster round with four pairs of curved setae.

Life history: The host is E. conspersum (Figs. 2-3). Eggs were adhered to the lower epidermis (abaxial) of the fronds, usually laid in a row or cluster of three to nine, slightly overlapping each other (Figs. 7-10), rarely in two rows. The mean number of eggs in each cluster was 4.5 (S.D.=1.15; $\mathrm{n}=42$ ). Usually one or two clusters of eggs were found per frond. However, in several cases up to four clusters were found in approximately 150 collected samples. The egg masses were observed between margin and midrib and in the mid- to upper portion of a frond. The pale, creamy-yellow egg color became translucent as the eggs aged. When larvae hatched, they directly started mining by breaking through the chorion, then the plant epidermis and mesophyll. At this stage, frass was deposited in eggshells (Figs. 
9-10) as larvae commenced mining. Time of larval hatching, starting point, and direction of mine were usually synchronized. Thus, larvae gregariously started mining in the same direction, in a line "shoulder to shoulder" (Figs. 11-12). Late instars were scattered throughout the mine (Figs. 13-14) and their frass pellets were clustered loosely, more along the midrib portion than the margin of the frond.

The leaf mine was formed initially as a broad linear-serpentine which eventually broadened more to a linear blotch, and finally a full blotch. In rare instances, early stage linear miners separated to form two linear mines. The mines fused when several batches of eggs were laid on the same frond. In a single case a new mine was formed in the remaining fresh part of an old mine. Additionally, under rearing conditions, from a batch of eight eggs laid in two rows, the larvae formed three linear-serpentine mines. As larvae continued mining, the final blotch mine obliterated the earlier linear-serpentine mine.

The mines were easily recognized by the brown-colored upper epidermis of the fronds. Recently mined portions were yellowish. Mature mines covered the width of midrib to the margin or the entire frond passing through the midrib. Occasionally, fronds were bent down from the base of the mature mine or the entire frond was dried and hanging down. Fronds with the eggs or leaf mines were seen more often in shady areas of the forest and were positioned at lower parts of a mass of ferns where mature and old fronds occur.

More than 30 specimens of an undescribed gregarious Proacrias sp. wasp (Eulophidae: Entedoninae), and a few specimens of an ichneumonid, Scambus emeritae Gauld (Pimplinae), were reared from the A. elaphoglossumae larvae.

Several leaf mines collected at early stages contained dead and desiccated early instar larvae. Under rearing and natural conditions, mid- to late instars were observed switching to different fronds by perforating the lower epidermis (Fig. 15). The larvae in mid- to late instars regurgitated a clear brown liquid when they were poked with an insect pin on their abdominal or thoracic segments. Five instars are believed to exist, based upon examination of larval head capsules and collections of preserved larvae.

The last instar mature larva made an elliptical to penelliptical exit hole or operculum (diameter: ca. $2 \mathrm{~mm}$ ) on the upper epidermis of fronds prior to pupation (Fig. 16). The larva spun a cocoon and pupated, positioning their head close to the operculum; when an operculum was opened manually, the pupa was observed easily through the hole (Figs. 17-18). The cremaster was attached with silk at the base of the cocoon. The pupal stage took about one month in the laboratory. The pupa protruded slightly, about $1 \mathrm{~mm}$ or less, from the operculum at the adult emergence. The majority of the cocoons were found in close proximity; each cocoon was about $13 \mathrm{~mm}$ long and $6 \mathrm{~mm}$ wide, constructed with silk, and laterally intermixed with frass pellet fragments which were accumulated at the midrib area.

Evidence suggests three generations per year: October-January, February-May, and June-September. Late instars collected in July, 2000, pupated in August, and adults emerged in September. Middle to late instars collected between January and early March, 2001 pupated from March to April and adults emerged from April to May. A few early stage live larvae were collected in late October, 2001. In early March, 2002, several mines with empty pupal shells (from which adults had emerged) and approximately 50 middle to late stage mines were collected with live third, fourth, and fifth instars and pupae.

In the field, no adults were observed flying or resting on or near host plants during the daytime. Adults of $A$. elaphoglossumae have not been collected at light — all the adult specimens have been reared.

Another host plant for A. elaphoglossumae is $E$. biolleyi $\mathrm{H}$. Christ. Two mature pupae were found in a blotch mine at the Genesis II Cloud Forest Reserve (2300 m elevation) in Cerro de la Muerte when this paper was in press.

Holotype: Male; COSTA RICA: San José Province: Cordillera de Talamanca, Cerro de la 
Muerte: Villa Mills, Georgina, $3000 \mathrm{~m}$ : larva coll. 9 Feb 2000, em. 28 Mar 2000, ex Elaphoglossum conspersum, K. Nishida (USNM).

Paratypes: COSTA RICA: Cartago Province, Turrialba: near CATIE Biological Station, 3000 m: 1 male, larva 31 Jan 1998, em. 30 Mar 1998; 1 male, em. 31 Mar 1998, D. R. Davis, slide USNM 32006. Same data as holotype except: 1 male, larva 2 Feb 2000, em. 25 Mar 2000; 1 male, em. 26 Mar 2000, slide USNM 110178; 2 males, 1 female, em. 28 Mar 2000, slide USNM 110167; 1 male, 1 female, em. 31 Mar 2000; 2 females, em. 3 Apr 2000; 2 males, 5 females, em. 5 Apr 2000; 3 males, em. 11 Apr 2000; 2 males, 1 female, em. 13 Apr 2000, slide USNM 32274; 2 females, em. 19 Apr 2000; 1 male, 1 female, em. 21 Apr 2000; 1 male, em. 26 Apr 2000; 3 males, em. 2 May 2000; 2 males, 2 females, em. 4 May 2000; 1 male, em. 6 May 2000. Paratypes deposited in The Natural History Museum, London, England; Universidad de Costa Rica, San Jose; Instituto Nacional de Biodiversidad (INBio), Santo Domingo de Heredia, Costa Rica; and the National Museum of Natural History, Smithsonian Institution, Washington, D.C., U.S.A..

Distribution: Cerro de la Muerte in Cordillera de Talamanca, Costa Rica, at high elevations between 2300 and $3100 \mathrm{~m}$.

Etymology: The specific name is derived from the generic name of the host, Elaphoglossum and is feminine.

Comparison to other taxa: A. elaphoglossumae is compared to $U$. polystichalis and species of Neurophyseta. Adults of U. polystichalis are much larger, $12-15 \mathrm{~mm}$ in wing length. The postmedial line of Neurophyseta curves basally, joining the medial line at $\mathrm{M}_{2}$. In $U$. polystichalis and $A$. elaphoglossumae the postmedial line continues to the posterior margin of the forewing. In the male genitalia of A. elaphoglossumae the sacculus is not prominent, but it is prominent in Neurophyseta; the gnathos is weakly dentate in U. polystichalis, and either dentate or entire in Neurophyseta. In the female genitalia of $U$. polystichalis the posterior apophyses are almost as long as the anterior apophyses, and in A. elaphoglossumae and Neurophyseta the anterior apophyses are four times as long as posterior apophyses. In A. elaphoglossumae the corpus bursae is membranous without a signum, in $U$. polystichalis it is densely and finely spinulate, without a signum; and in Neurophyseta it is membranous or not, with or without a signum. In A. elaphoglossumae and Neurophyseta both sexes have bullae tympani that are the same size, but in $U$. polystichalis they are more enlarged in the female than the male. Processus tympani are present and prominent in $U$. polystichalis and Neurophyseta, but absent in A. elaphoglossumae. Ramus tympani are present, and highly sclerotized in A. elaphoglossumae, but absent in U. polystichalis and Neurophyseta. The larval segments of $U$. polystichalis do not have medially located dorsal and ventral sclerotized plates as in A. elaphoglossumae. The head of $U$. polystichalis is semiprognathous; in $A$. elaphoglossumae it is prognathous. The pupa of $U$. polystichalis has a round cremaster with two dorsal, mediolateral conical protuberances with straight setae.

The biology of $U$. polystichalis on the leather-leaf fern was described by Kuitert and Dekle (1962). They did not observe the egg so it is not known whether $U$. polystichalis lays eggs singly or in clusters. The larvae of $U$. polystichalis bore the midvein of tender fronds, and the larvae of $A$. elaphoglossumae mine mid- to upper portion of mature old frond entirely. The larval behavior of A. elaphoglossumae and $U$. polystichalis are somewhat similar, being endophagous, and the larva cuts an operculum for eclosion of the adult. However, A. elaphoglossumae pupates right at the exit hole in the frond and $U$. polystichalis pupates approximately one to two inches below the exit hole in the petiole.

The gregarious mining behavior of $A$. elaphoglossumae is remarkably similar to that of an undescribed species of Chrysaster Kumata (Gracillaridae), discovered by D. Wagner and D. Davis in Florida, USA, and by D. Davis in Cuba (unpublished). Larvae of this Chrysaster species also emerge synchronously from a 
single row of eggs to mine initially in a contiguous group and later disperse to form a large blotch mine.

\section{DISCUSSION}

Although pteridophagy, or fern-feeding, is considered uncommon among Lepidoptera, there are examples of fern-feeders throughout the most diverse superfamilies of Ditrysia, the Noctuoidea, Geometroidea, and Pyraloidea, and also in primitive moth groups such as Tineoidea and Gelechioidea (e.g. Balick et al. 1978, Kirk 1982, Weintraub et al. 1995). In the Western Hemisphere there are very few well-documented studies of pyraloid fern-feeders, but well-known examples in the U.S. of Herpetogramma Lederer (Crambidae: Spilomelinae) include $H$. aeglealis (Walker) (Forbes 1923, Ruehlmann 1988) and H. theseusalis (Walker) (Forbes 1923). There are records of pyraloids feeding on aquatic ferns of the family Salvinaceae, i.e. Samea multiplicalis (Guenée) (Crambidae: Spilomelinae) on Salvinia Séguier and Azolla Lam. (Knopf and Habeck 1976) and Parapoynx allionealis Walker (Crambidae: Nymphulinae) on Salvinia rotundifolia Willd. (Habeck 1974). The latter were discovered during exploration for biological control agents of invasive aquatic weeds.

Other published feeding records for the Musotiminae until the late 1990's include Musotima dryopterisivora Yoshiyasu (orginally identified as M. acclaralis Walker) reared on Dryopteris prob. chinensis (Baker) Koidz. (Dryopteridaceae) in Japan (Nakamura 1977), Musotima nitidalis Walker on Adiantum L. (Pteridaceae), Histiopteris incisa (Thunb.) J. Sm. (Dennstaedtiaceae) (Meyrick 1885, Philpott 1917), and Musotima aduncalis Felder and Rogenhofer on Adiantum sp. from New Zealand (Hudson 1928). A species of Panotima Meyrick from South Africa was reared on Pteridium aquilinum (L.) (Kuhn) (Dennstaedtiaceae), known as bracken fern, during exploration for biological control agents (Lawton et al. 1988).
Recent research indicates that Musotiminae may harbor more undiscovered fern-feeders. In Costa Rica extensive UV light collecting by INBio parataxonomists did not produce large numbers of specimens of Musotiminae, with the exception perhaps of Neurophyseta. M. Alma Solis (MAS) and Eugenie Phillips (INBio) discovered during fieldwork in Costa Rica that musotimine species, particularly of Undulambia, attracted by ultraviolet light did not rest on the collecting sheet, but on surrounding vegetation, which may explain the low numbers collected by UV light. The current success in discovery of new species in this subfamily has been through visual inspection of host plants for larval damage. In 2002, a N. camptogrammalis (determined by MAS) was reared from Alsophila firma fern (voucher no. 02-SNRP-602 in Janzen and Hallwachs database homepage). In southeast Asia and Australia recent exploration by visual inspection for biological control agents of Lygodium microphyllum (Cav.) R. Br., the Old World climbing fern, resulted in the discovery of other new fern-feeding genera of Musotiminae by the Agriculture Research Service, Australian Biological Control Laboratory (USDA) in Indooroopilly, Queensland (Solis et al. 2004, Yen et al. 2004).

Further exploration by visual inspection of Elaphoglossum species worldwide may uncover more new species of Albusambia and other Pyraloidea species. KN recently discovered mines on several species of Elaphoglossum and reared some other Pyraloidea species. Elaphoglossum, host of A. elaphoglossumae in Costa Rica, contains over 600 species, with approximately $90 \%$ occurring in the Neotropics and the remainder in tropical Africa, Asia, Australia, and certain Pacific islands (Mickel and Atehortua 1980). Herbarium specimens of E. conspersum at the INBio indicate a broad distribution in Costa Rica, and with further exploration, perhaps for A. elaphoglossumae.

Finally, it is noteworthy to report the discovery of one or two species of Bradysia (Diptera: Sciaridae), a gregarious frond-miner on $E$. biolleyi and other species of Elaphoglossum in mid-elevation cloud forests between 2000 and 
2300 m, in Volcán Barva and Cordillera de Talamanca. The leaf-mining biology of these sciarids is similar to that of the Albusambia (W. Mohrig and K. Nishida, in preparation).

\section{ACKNOWLEDGMENTS}

Research on Costa Rican Pyraloidea by MAS is supported by the Systematic Entomology Laboratory, PSI, ARS, USDA, and INBio. The fieldwork of DRD in Costa Rica was supported by a Research Opportunity Fund award from the Smithsonian Institution and the ALAS III project (supported by National Science Foundation grant DEB-9706976). David Wagner (University of Connecticut, Storrs, U.S.A.) accompanied DRD in the initial discovery of this species.

David B. Lellinger, Department of Systematic Biology, Smithsonian Institution, identified the host fern and provided related information. Christer Hansson, Department of Zoology, Lund University, and Paul Hanson, Escuela de Biología, UCR, identified the parasitoid wasps.

\section{RESUMEN}

Se describen un género y especie nuevos de Musotiminae, Albusambia elaphoglossumae Solis and Davis, de Costa Rica. Esta especie mina las frondas del helecho Elaphoglossum conspersum. La serie tipo se obtuvo mediante la recolección de las minas y mediante crianza en laboratorio. El adulto se define por caracteres específicos en el aparato genital; la pupa se caracteriza por una depresión media en el vértex y por dos estructuras anterolaterales en forma de cuernos en el protórax. La larva es un minador gregario de la fronda, con su cuerpo aplanado dorsoventralmente y su cabeza prognata; ambas adaptaciones morfológicas para minar frondas (vistas por primera vez en Musotiminae). Actualmente, Musotiminae es de alta prioridad en la búsqueda de nuevos agentes para el control biológico de helechos invasores.

Palabras claves: Elaphoglossum conspersum, larvas gregarias, helecho, minador de hojas, neotropical, Neurophyseta, Proacrias, Undulambia.

\section{REFERENCES}

Balick, M.J., D.G. Furth \& G. Cooper-Driver. 1978. Biochemical and evolutionary aspects of arthropod predation on ferns. Oecol. 35: 55-89.

Capps, H.W. 1965. A new Undulambia species on leather-leaf fern in Florida, and note on a closely related Central American species (Lepidoptera: Pyraustidae, Nymphulinae). Fl. Ent. 48: 155-157.

Forbes, W.T.M. 1923. The Lepidoptera of New York and neighboring states. Cornell Univ, Agr. Exp. Sta. 68: $1-729$.

Habeck, D.H. 1974. Caterpillars of Parapoynx in relation to aquatic plants in Florida. Hyacinth Cont. J. 12: 15-18.

Hartshorn, G.S. 1983. Plants: Introduction, p. 118-157. In D.H. Janzen, (ed.) Costa Rican Natural History. Chicago University Press, Chicago. xi +816 p.

Hudson, G.V. 1928. The butterflies and moths of New Zealand. Ferguson and Osborn Ltd., Wellington. $386 \mathrm{p}$.

Kappelle, M. 1996. Los bosques de roble (Quercus) de la Cordillera de Talamanca, Costa Rica: Biodiversidad, Ecología, Conservación y Desarollo. Unversidad de Amsterdam/Instituto Nacional de Biodiversidad, Costa Rica. XVI + 391 p.

Kirk, A.A. 1982. Insects associated with bracken fern Pteridium aquilinum (Polypodiaceae) in Papua New Guinea and their possible use in biological control. Act. Oecol./Oecol. Appl. 3: 342-359.

Knopf, K.W. \& D.H. Habeck. 1976. Life history and biology of Samea multiplicalis. Env. Entomol. 5: 539-542.

Kuitert, L.C. \& G.W. Dekle. 1962. Mysterious invader. Sunshine State Agricultural Report, Agricultural Experiment Station, University of Florida, Gainesville, Florida. 7(3): 10-12.

Lange, W. Harry, Jr. 1956. A generic revision of the aquatic moths of North America (Lepidoptera: Pyralidae: Nymphulinae). Wasmann J. Biol. 14(1): 59-144.

Lawton, J.H., V.K. Rashbrook \& S.G. Compton. 1988. Biocontrol of British bracken: the potential of two moths from Southern Africa. Ann. Appl. Biol. 112: 479-490.

Meyrick, E. 1885. Descriptions of New Zealand Microlepidoptera. 6. Pyralidina. Trans and Proc. New Zealand Inst.17: 121-140. 
Mickel, J.T. \& L. Atehortua. 1980. Subdivision of the genus Elaphoglossum. Am. Fern J. 70: 47-68.

Minet, J. 1985. Étude morphologique et phylogénétique des organs tympanique des Pyraloidea. 2- Pyralidae: Crambinae, première partie. (Lepidoptera: Glossata). Annls. Soc. ent. Fr. 21(1): 69-86.

Munroe, E.G. 1972. Pyraloidea (in part). In R. B. Dominick, et al. The Moths of America North of Mexico. Fasc. 13.1A. Curwen, London, 134 p.

Nakamura, M. 1977. Notes on the immature stage of Musotima acclaralis Walker (Lep.: Pyralidae). Kita-Kyushu no Konchu. 23: 3-36.

Phillips, E. \& M.A. Solis. 1996. Neurophyseta (Lepidoptera: Crambidae) de Costa Rica. Rev. Biol. Trop. 44: 693-717.

Philpott, A. 1917. A list of Lepidoptera of Otago. Trans and Proc. New Zealand Inst. 49: 195-238.

Ruehlmann, T.E., R.W. Matthews \& J.R. Matthews.1988 Roles for structural and temporal shelter-changing by fern-feeding lepidopteran larvae. Oecol. 75: 228-232.

Solis, M.A., S.-H. Yen \& J.H. Goolsby. 2004. Species of Lygomusotima new genus and Neomusotima Yoshiyasu (Lepidoptera: Crambidae) form Australia and southeastern Asia feeding on Lygodium microphyllum (Schizaceae). Ann. Entomol. Soc. Am. 97: 64-76.
Speidel, W. 1984. Die Abgrenzung der Unterfamilie Acentropinae (Lepidoptera: Pyraloidea). Atalanta. 12(2): 117-128.

Weintraub, J.D., J.H. Lawton \& M.J. Scoble. 1995. Lithinine moths on ferns: a phylogenetic study of insect-plant interactions. Biol. J. Linn. Soc. 55: 239-250.

Yen, S.-H. 1996. Aeolopetra lanyuensis Yen, a new pyralid moth (Pyralidae: Musotiminae) from Taiwan. Tinea. 14(4): 29-299.

Yen,S.-H., M.A. Solis \& J.H.Goolsby.2004.Austromusotima, a new musotimine genus (Lepidoptera:Crambidae) feeding on Old World climbing fern (Lygodium microphyllum (Schizaeaceae). Ann. Entomol. Soc. Am. 97: 397-410.

Yoshiyasu, Y. 1985. A systematic study of the Nymphulinae and the Musotiminae of Japan (Lepidoptera: Pyralidae). Scient. Rep. Kyoto. prefect. Univ. (Agr.). 37: 1-162.

\section{INTERNET REFERENCES}

Janzen, D.H. \& W. Hallwachs. 2005. Database homepage. Caterpillars, pupae, butterflies and moths of the ACG. http://janzen.sas.upenn.edu/caterpillars/database.lasso; downloaded 2-II-2005. 

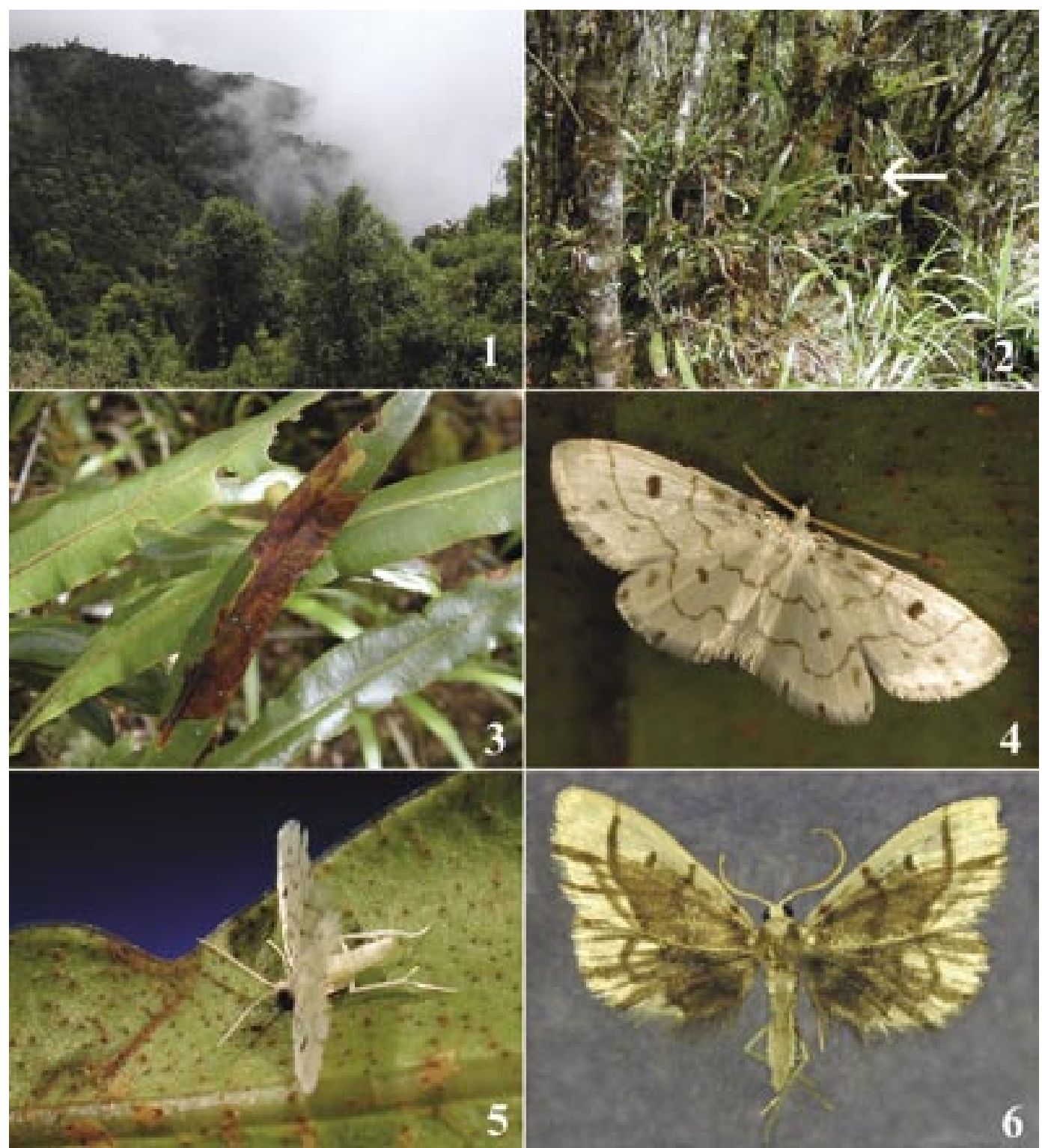

Figs. 1-2. General habitat of A. elaphoglossumae and its host, E. conspersum (see arrow in the fig. 2), on Villa Mills, Cerro de la Muerte, Costa Rica. 3) Mined frond of E. conspersum. 4-5) Normal color phase male adult in wings raised in display posture. 4) Frontal view. 5) Dorsolateral view. 6) Dark color phase of prepared adult specimen. 

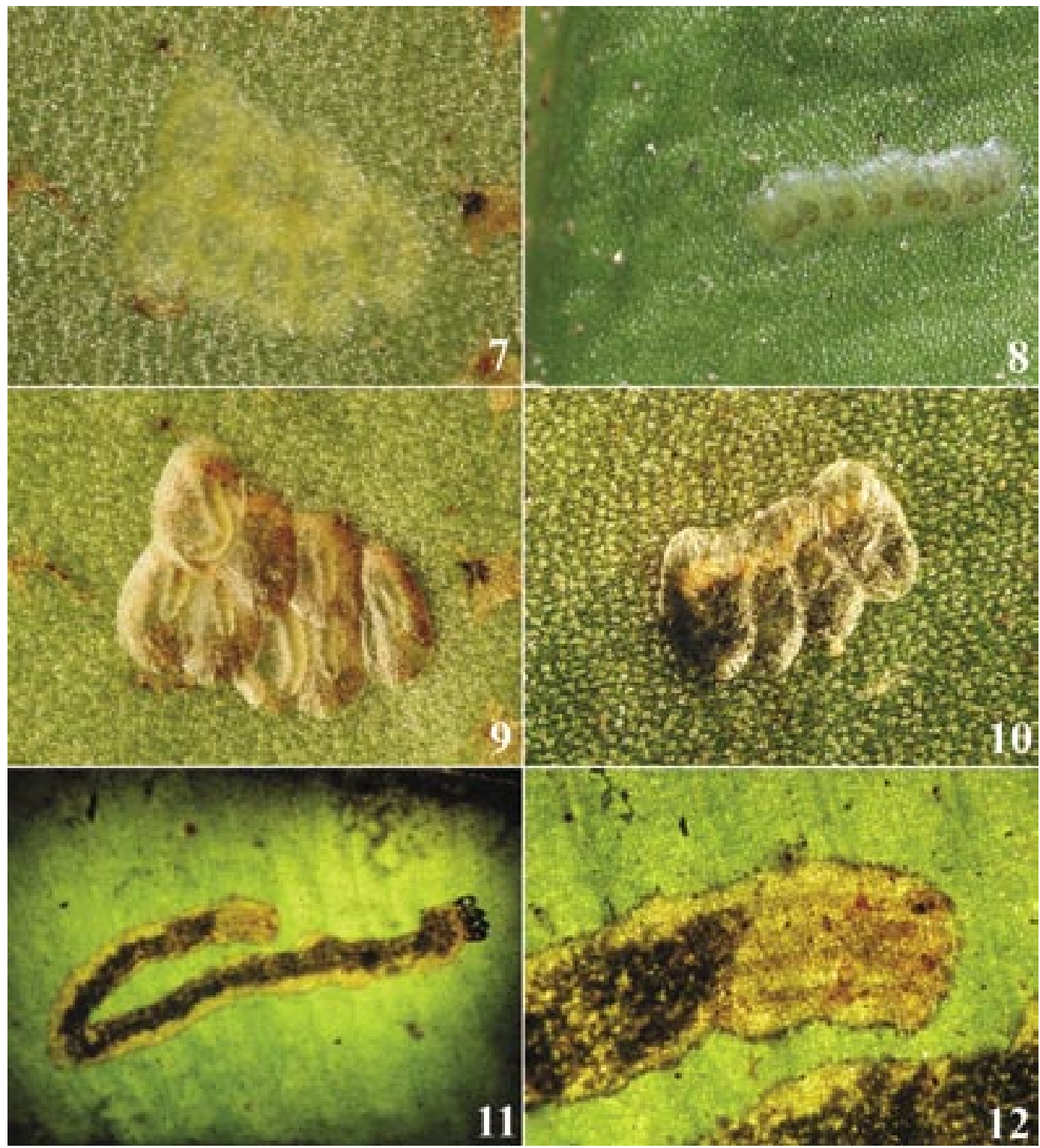

Figs. 7-12. Immature stages of $A$. elaphoglossumae. 7) Two transverse rows of eight freshly laid eggs. 8) Transverse row of eight mature eggs, with larval head capsules visible. 9) First instar larvae directly mining into mesophyll (same eggs shown in fig. 7). 10) Four abandoned eggs filled with first instar larval frass. 11) Early linear mine initiated by four larvae; transverse row of four eggshells visible on right. 12) Four early instars feeding contiguously at termination of mine (close up of fig. 11). 

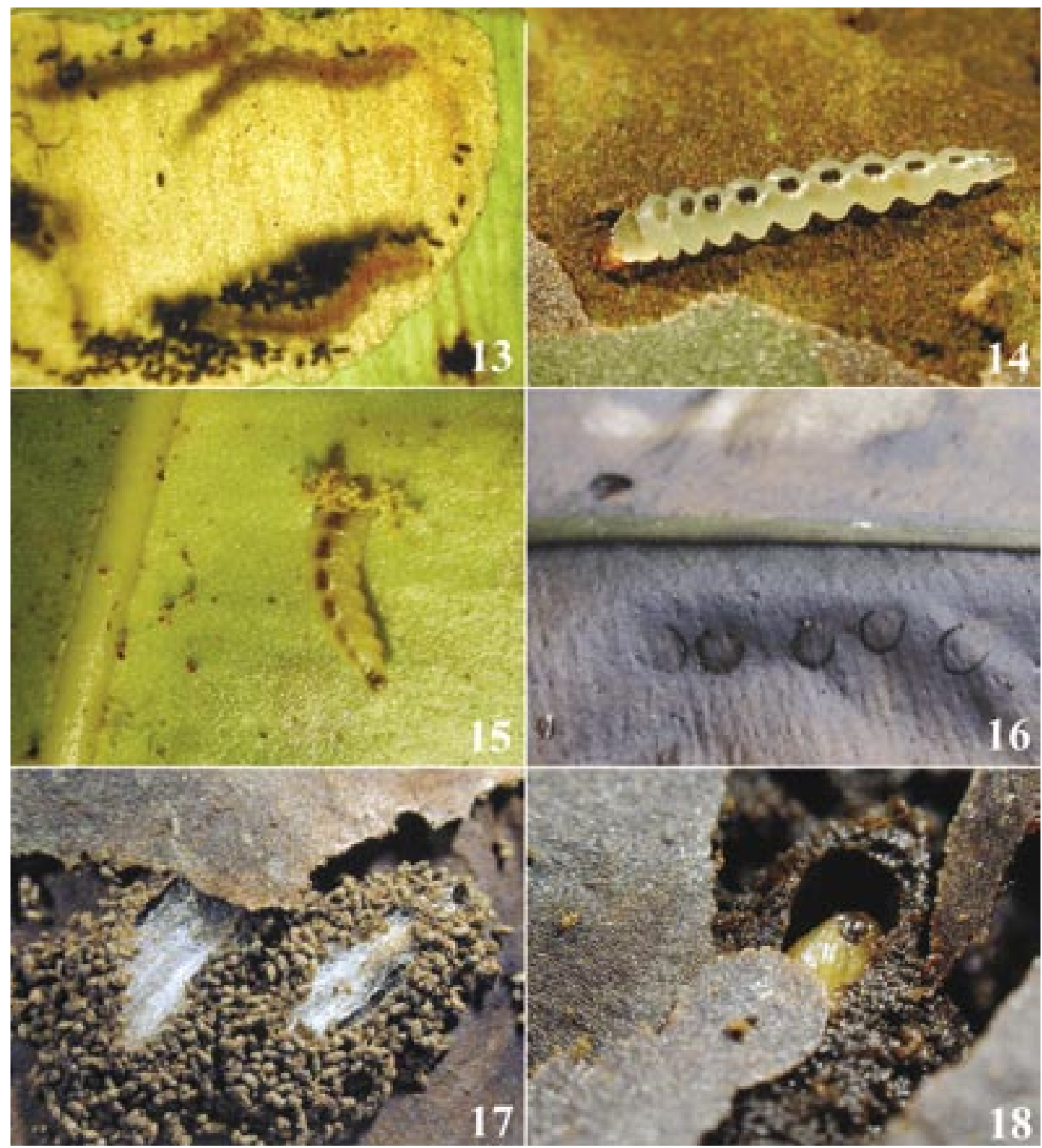

Figs. 13-18. Immature stages of A. elaphoglossumae. 13) Later instars dispersed in blotch mine (length of larvae $~ 11.5$ $\mathrm{mm}$ ). 14) Fourth instar larvae before molting to fifth instar (mine is opened to show the larva). 15) Mature larva initiating a new mine. 16) Six pupal exit holes on dead frond (note: holes are located close to each other). 17) Cocoons (lower plant epidermis removed to show the cocoons). 18) Opened pupal chamber showing pupa in situ. 

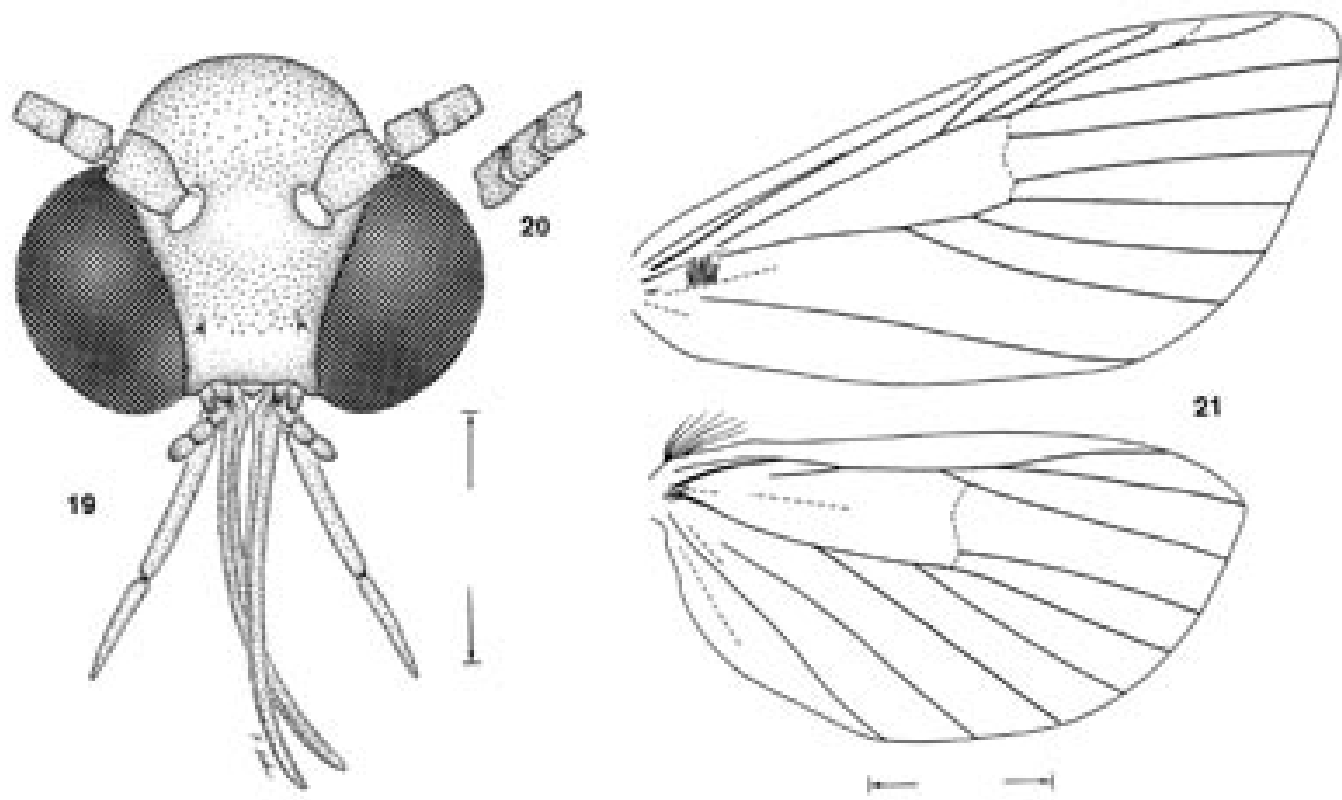

21
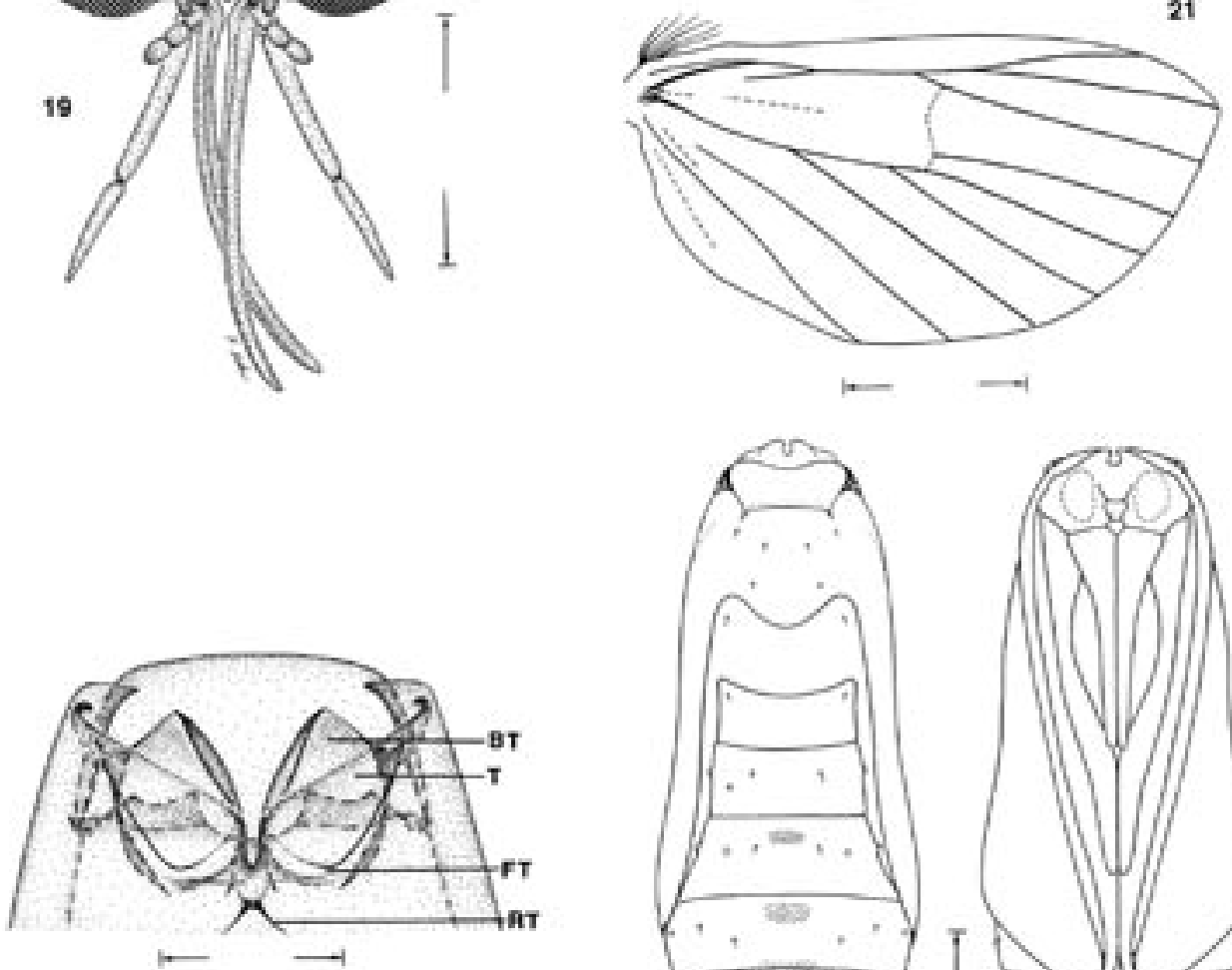

22

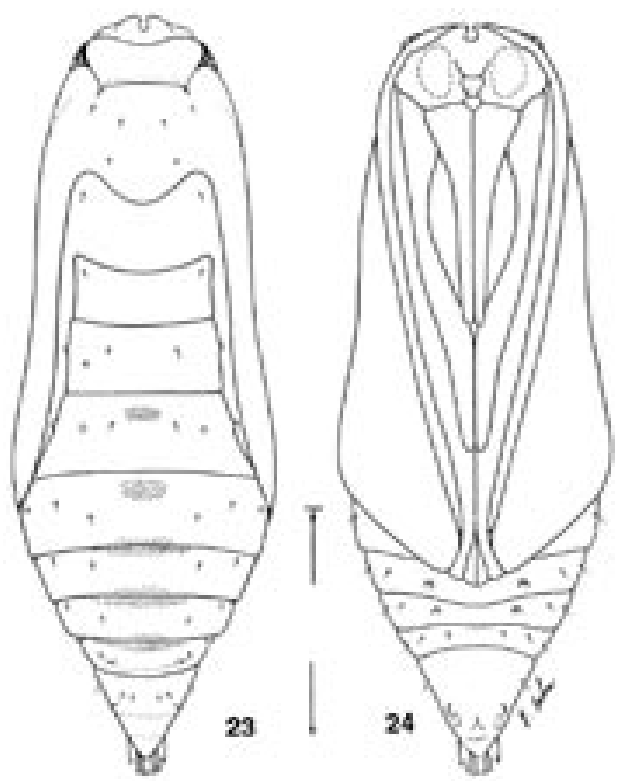

Figs. 19-24. A. elaphoglossumae adult and pupal morphology. 19) Head (0.5 mm). 20) Antennal segments 6-8. 21) Wing venation. 22) Tympanal organ of second abdominal sternum (BT = bulla tympani; $\mathrm{FT}=$ fornix tympani; $\mathrm{RT}=$ ramus tympani; $\mathrm{T}=$ tympanum). 23) Pupa, dorsal view (2 mm). 24) Pupa, ventral view. 

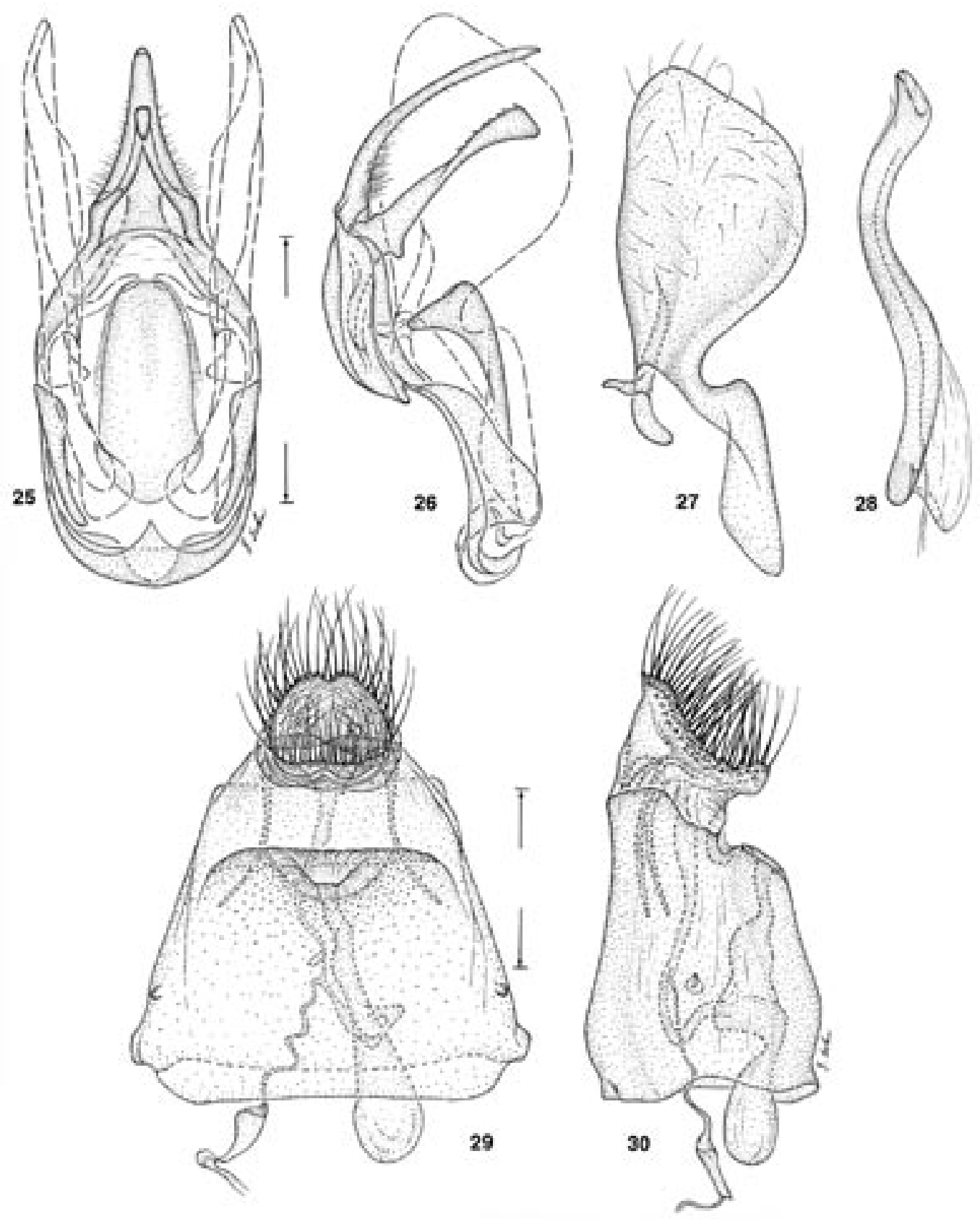

Figs. 25-26. Genitalia. 25) Male, ventral view (0.5 mm). 26) Lateral view of Figs. 19. 27) Valva, mesal view. 28) Aedeagus, lateral view. 29) Female, ventral view (0.5 mm). 30) Lateral view of Fig. 23. 

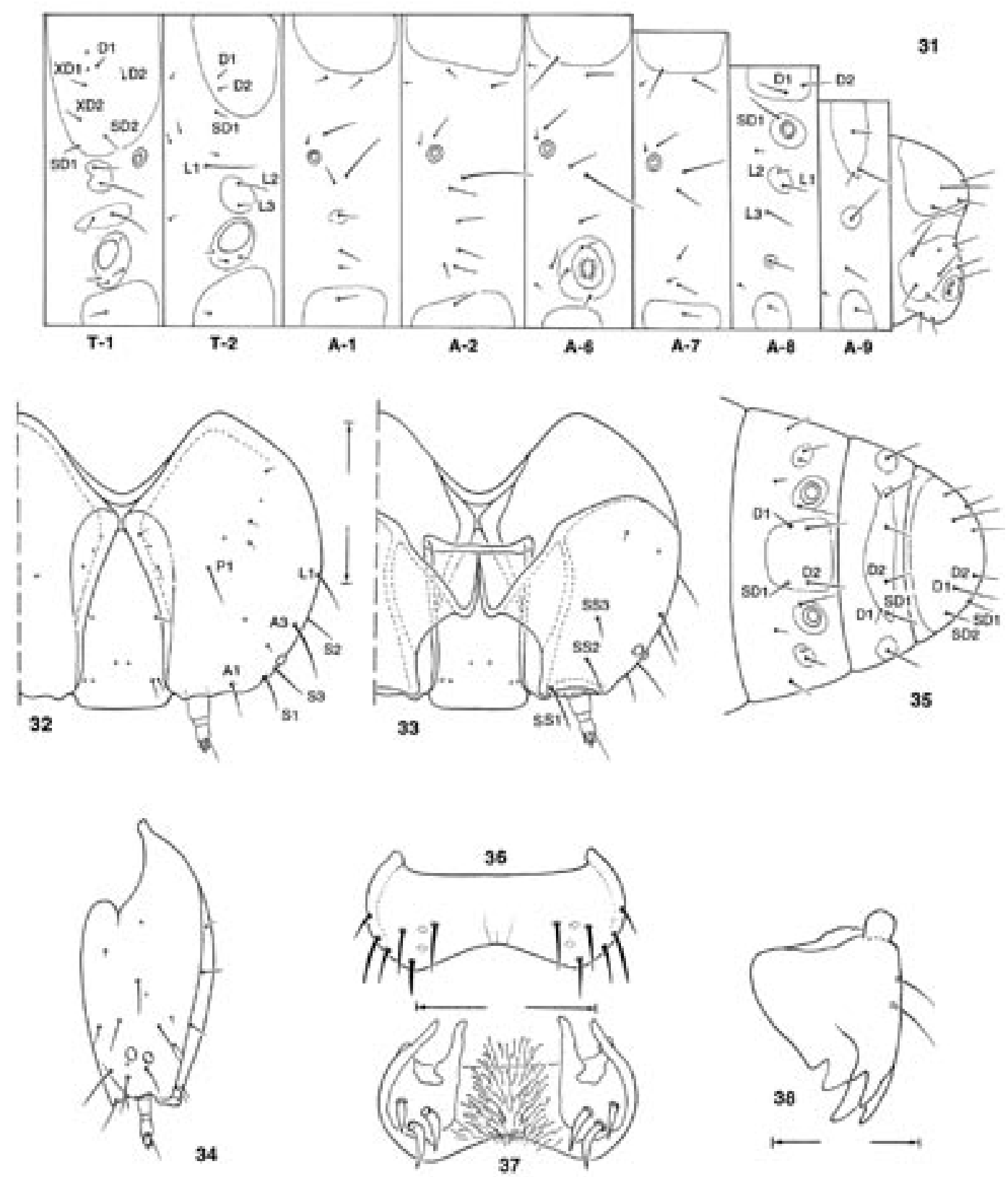

Figs. 31-38. A. elaphoglossumae chaetotaxy of late instar larva. 31) Lateral schematic of prothorax, mesothorax, and abdominal segments 1, 2, 6-10. 32) Head, dorsal view (0.5 mm). 33) Head ventral view. 34) Head lateral view. 35) Dorsal view of abdominal segments 8-10. 36) Labrum, dorsal view. 37) Labrum ventral view. 38) Mandible. (Scale lengths in parentheses). 
